\title{
Blood levels of the micronutrient zinc decrease with advancing age in normally nourished elderly persons
}

\author{
Michiyo Takahashi ${ }^{{ }^{*}}$, Ayumi Takagi ${ }^{2}$, Toshikazu Suzuki ${ }^{1,2}$, Hikaru Matsumoto 1,2 \\ From Metabolism, diet and disease \\ Washington, DC, USA. 29-31 May 2012
}

\section{Background}

The prevalence of malnutrition in elderly populations has emerged as a social issue. Malnutrition can cause significant deterioration of health, impede individuals' independence and quality of life, and increase morbidity and mortality rates. Early detection and prompt treatment are very important in preventing malnutrition. The Mini Nutritional Assessment $\left(\mathrm{MNA}^{\circledR}\right)$ is now widely used for nutrition screening and as an assessment tool for elderly persons aged over 65 years. In this study, we investigated which blood nutrients were liable to decrease with advancing age in healthy elderly persons who were classified as normally nourished.

\section{Materials and methods}

The participants comprised 13 elderly adults ( 7 men and 6 women, mean age $82.5 \pm 5.2$ years), belonging to a senior citizens' club in Ichikawa City, Japan. An individual's physical composition was analyzed using anthropometric parameters. The Nutrition status Mini Nutritional Assessment comprising 18 questions (the full $\mathrm{MNA}^{\circledR}$ ) and a brief-type self-administered diet history questionnaire (BDHQ) were used to evaluate the nutritional status and dietary intake of subjects, respectively. The levels of various nutrients in the blood were determined by laboratory biochemical blood tests. Measurements were performed in December 2011 and the data were compared with data obtained from the same participants two and half years ago (March 2009) [1].

'Graduate School of Human Ecology, Wayo Women's University, Ichikawa,

Chiba 272-8533, Japan

Full list of author information is available at the end of the article

\section{Results}

The average screening score of the full MNA ${ }^{\circledR}$ from March 2009 and December 2011 was $26.7 \pm 1.3$ and $27.5 \pm 1.3$, respectively. The estimated nutrient intake measured by BDHQ analysis revealed all participants were well nourished. The Body Mass Index score from December $2011(23.0 \pm 1.8)$ was slightly but significantly lower $(p<0.01)$ than that from March $2009(23.5 \pm 2.0)$. Although the concentration of red blood cells, hematocrit, hemoglobin content, and serum levels of total protein, albumin, and iron were not significantly different compared with the original measurements (two years and nine months previously), these values appeared to be declining. However, the levels of serum zinc had decreased by $22 \%$ during the last 2 years 9 months $(p<0.001)$, although levels were still within the normal range.

\section{Conclusions}

The results presented here suggest that elderly people might become susceptible to zinc insufficiency with increasing age, even if they are considered well-nourished. Zinc deficiency causes significant impairment of both the adaptive and innate immune responses, and is important for promoting systemic inflammation [2]. Therefore, it is important for nutritionists to monitor the consumption of micronutrients such as zinc more carefully, in order to maintain and enhance the quality of life in elderly people.

\section{Author details}

'Graduate School of Human Ecology, Wayo Women's University, Ichikawa, Chiba 272-8533, Japan. Department of Health and Nutrition, Wayo Women's University, Ichikawa, Chiba 272-8533, Japan.

Published: 1 June 2012 


\section{References}

1. Ito $\mathrm{K}$, Uchida N, Hashizume N, Matsumoto $\mathrm{H}$, Ihara $\mathrm{H}$ : Assessment of the nutritional status of elder people who spent self-reliant life and were hospitalized by means of dietary parameters and biochemical blood test. In J Jpn Soc Clin Nutr. Volume 30. Japanese; 2009:167.

2. Wong $\mathrm{CP}, \mathrm{Ho}$ E: Zinc and its role in age-related inflammation and immune dysfunction. Mol Nutr Food Res 2012, 56:77-87.

doi:10.1186/1753-6561-6-S3-P48

Cite this article as: Takahashi et al: Blood levels of the micronutrient zinc decrease with advancing age in normally nourished elderly persons. BMC Proceedings 2012 6(Suppl 3):P48.

Submit your next manuscript to BioMed Central and take full advantage of:

- Convenient online submission

- Thorough peer review

- No space constraints or color figure charges

- Immediate publication on acceptance

- Inclusion in PubMed, CAS, Scopus and Google Scholar

- Research which is freely available for redistribution

Submit your manuscript at www.biomedcentral.com/submit 